\title{
The double psychological contracts of temporary agency workers
}

\author{
Manuela Morf; Alexandra Arnold; Bruno Staffelbach \\ Center for Human Resource Management (CEHRM), University of Lucerne
}

Published in:

Employee Relations

DOI: 1108/ER-03-2013-0026

Document Version Pre-copyedited manuscript. People interested in the research are advised to contact the authors (manuela.morf@unilu.ch) for the final version of the publication, or visit the publisher's web-site.

Link to publication:

https://www.emerald.com/insight/content/doi/10.1108/ER-03-2013-0026/full/html

Citation for published version (APA): Morf, M., Arnold, A. \& Staffelbach, B. (2014). The double psychological contracts of temporary agency workers. Employee Relations, 36(6), 708-726. doi: 10.1108/JMP-02-2017-0048

Acknowledgments: This research received no specific grant from any funding agency or other third party in the public, commercial, or not-for-profit sectors. The authors thank the Swiss temporary work agency that provided us with a sample of e-mail addresses of their temporary agency workers. An earlier version of this manuscript was part of the first author's master's thesis. 


\title{
The double psychological contracts of temporary agency workers
}

\begin{abstract}
Purpose: This explorative study aims to investigate how temporary agency workers' job attitudes are influenced by the fulfilment of the psychological contract; a set of employees' expectations, formed with the temporary work agency and its client: the host organisation.

Design/methodology/approach: We estimated moderated regressions with data collected through an online survey of 352 temporary agency workers employed by a large temporary work agency in Switzerland.

Findings: Results suggest that temporary agency workers' job satisfaction, commitment towards the host organisation, and intentions to stay with the temporary work agency relate positively to the fulfilment of the psychological contract by both organisations. Additionally, reported spill-over-effects imply that the fulfilment of the psychological contract by one organisation moderates job attitudes towards the other organisations.

Research limitations/implications: Results of our explorative study reveal that future research should consider the interrelated nature of psychological contracts in working arrangements when multiple employers are involved. However, for more generalisable results, a greater international sample, including different temporary work agencies, would be favourable.

Practical implications: Findings will help temporary work agencies to better understand how they rely on host organisations to fulfil the temporary agency workers' psychological contract to attract and retain temporary agency workers.

Originality/value: This paper contributes to the literature in the understudied field of non-traditional work arrangements as one of the few to examine these spill-over-effects both empirically and theoretically.
\end{abstract}

Keywords: Psychological contracts, Temporary workers, Employee attitudes, Employee behaviour

Article classification: Research paper 


\section{Introduction}

The number of temporary agency workers (temps) has doubled in the last decade in Europe, and a further increase is expected (de Cuyper et al., 2008). Similar developments can be found in the United States of America (van Breugel et al., 2005) and in Asia (Liu et al., 2010). Moreover, in Switzerland, where our explorative study was conducted, the number of temps is almost three times as high as it was 20 years ago (Rosinger and Djurdjevic, 2007). Temporary agency work is characteristically short-term in nature, with a shared employer role between the temporary work agency (agency) that contracts the temp and the host organisation (host) that leases the temp's labour work from the agency (Claes, 2005; Svensson and Wolvén, 2010). The market for temps has grown and become more competitive, thereby, being able to attract and retain the best temps is a competitive advantage for agencies (Liu et al., 2010; van Breugel et al., 2005). For this reason, agencies need to understand how to develop and maintain employee-employer-relationships with their temps.

To understand employee-employer-relationships, a great body of research has adopted psychological contract as a theoretical foundation (Conway and Briner, 2005; Rousseau, 1995; Zhao et al., 2007). According to psychological contract theory, employees hold a set of implicit expectations (the psychological contract) about what they feel committed or obligated to provide to the employer (e.g. productivity), and what their employer is obligated to provide them (e.g. salary or career opportunities). In other words, employees perceive the employee-employer-relationship as a reciprocal exchange (Rousseau, 1995). In contrast to traditional employee-employer-relationships, the employer role in temporary agency work is divided between the host and agency. As a consequence, temps form dyadic psychological contracts with the host and the agency (Cullinane and Dundon, 2006; Marks, 2001; McLean Parks et al., 1998).

Various studies have investigated how employment outcomes of workers with fixed-term contracts differ from traditional workers. However, these results are inconsistent; indicating the short-term nature of work is not the only factor influencing temps' job attitudes and behaviours (de Cuyper et al., 2008; Guest, 2004). In contrast, some studies support the fact that the fulfilment of psychological contract in general is a good predictor of employee job attitudes and behaviours (Guest, 2004; Van Dyne and Ang, 1998). Moreover, findings imply that employees' attitudinal responses to fulfilled psychological contracts in non-traditional work arrangements might differ from employees in traditional work arrangements (Guest, 2004). Consequently, the existing findings linking traditional workers' psychological contracts to job attitudes should not be generalised (Claes, 2005; McLean Parks et al., 1998; Svensson and Wolvén, 2010). To gain more insight into the impact of psychological contracts on job attitudes in non-traditional employment settings, further empirical study is required (Guest, 2004; McLean Parks et al., 1998; Svensson and Wolvén, 2010). 
Accordingly, this paper aims to contribute to the literature of multiple psychological contracts by investigating the effect of a dyadic psychological contract fulfilled by the agency and by the host on temps' job attitudes. Specifically, the job attitudes we examine include job satisfaction and affective commitment towards the agency and the host, because these two attitudes strongly influence job behaviours (e.g. job performance), which is of relevance to employers (Judge et al., 2001; Meyer et al., 1989). However, the management of job attitudes in a multiple employer setting remains unclear (Burgess and Connell, 2006; Liden et al., 2003; van Breugel et al., 2005). Accounting for the fact that the agency is not only the employer of the temp, but also its provider of placement services (Liu et al., 2010; van Breugel et al., 2005), we also investigated the impact of a fulfilled psychological contract on intentions to stay with the agency for future short-term assignments.

Moreover, in the triangular relationship between temp, agency, and host, elements of indirect reciprocity exist (Molm et al., 2007; Seinen and Schram, 2001). For example, the temp performs at the host, the host pays the leasing fees to the agency, and the agency provides services and the temp's wages. In such exchange relationships with three parties, the individual's evaluation of the relationship with one interaction partner is not independent from the evaluation of the relationship with the other partner. Laboratory experiments show that individuals develop more positive attitudes towards their exchange partners when exchange was working well in a multilateral rather than a bilateral relationship (Molm et al., 2007; Yamagishi and Cook, 1993). Indirect exchanges also have a higher risk of unbalanced, asymmetric outcomes than direct exchanges. Thus, fair outcomes in the indirect exchange lead to more positive perceptions of the interaction partners (Molm et al., 2007). Finally, when more than two parties are involved in an exchange, individuals believe in the existence of shared group norms, which might lead to more favourable attitudes towards others (Blau, 1967; Molm et al., 2007; Seinen and Schram, 2001).

This attitudinal spill-over-effect is also in line with social balance theory, namely, that individuals seek to eliminate perceived cognitive inconsistencies in groups by adjusting their attitudes towards one group member to the dominating attitudes in the group (Cartwright and Harary, 1956; Heider, 1958). For example, a temp that has a good relationship with the agency might adjust an attitude towards the host that was initially bad, to restore social balance. Yet, little research has examined the consequences that the multiple employers of temps might have on their job attitudes (Claes, 2005; Liu et al., 2010). Thus, our study addresses this research gap by investigating how fulfilment of the psychological contract by the agency interacts with the fulfilment of the psychological contract by the host in an online survey of temps $(\mathrm{N}=352)$ employed by a large agency in Switzerland. 


\section{Temps' psychological contracts}

The psychological contract reflects an employee's subjective perception of the employee-employer exchange relationship, in which the expectations of the employee are juxtapositioned with the expectations of the employer (Conway and Briner, 2005; Rousseau, 1995). An employee's willingness to fulfil the employers' perceived expectations depends on the extent to which an employee believes that his or her expectations will be met by the employer. Thus, the psychological contract should only contain expectations which are seen as being promised and likely (Rousseau, 1995).

Claes' (2005) work suggested that a temp forms a separate psychological contract with the host as well as with the agency and judges the fulfilment of each independently. Furthermore, several studies indicate that workers in general can form psychological contracts with multiple agents. For example, Svensson and Wolvén (2010) showed that temps simultaneously maintain a psychological contract with their manager and co-workers at the host. Barringer and Sturman (1998) showed that temps judge the host and the agency independently with regards to the fulfilment of a particular expectation, such as organisational support. Thus, temps' formation of a psychological contract with the agency and with the host must be considered when studying the relationship between the fulfilment of the psychological contract and temps' job attitudes. Furthermore, it appears that the fulfilment of the psychological contract by an organisation effects temps' job attitude towards the other organisation. Even though the theory of psychological contract regarding multi-sided employment is limited, and empirical study of this question is still new, theorists agree that such spill-over-effects are likely to occur (Cullinane and Dundon, 2006; Guest, 1998; Marks, 2001).

\section{Effects of fulfilment in dyadic psychological contracts}

In the following, we develop hypotheses about the effects of the psychological contract fulfilment on temps' job satisfaction, affective commitment towards the host and the agency, and intentions to stay with the agency (see Figure 1). 


\section{Job satisfaction}

Job satisfaction describes a job attitude based on an employee's valuation of all components and aspects related to the work, for example, working content, wage, team culture, and so forth (Spector, 1997). A positive valuation is the result of expectations regarding these work components being met. As the psychological contract of an employee includes all expectations, which he or she demands the employer fulfil, a fulfilled psychological contract leads to an employee's higher level of job satisfaction (Zhao et al., 2007).

Various studies show evidence that the work content is the most important influencing factor regarding job satisfaction. Other factors like payment or promotion opportunities are, in contrast, only of secondary importance (Saari and Judge, 2004). Moreover, Mueller and Lawler (1999) conclude that the more distant an organisation is perceived by an employee, the less it is perceived as being accountable for the work conditions. In this respect, the agency only determines the temps' work from afar, for example, by setting wages or providing social employment insurance. The day-to-day work, however, takes place at the host (Gallagher and Parks, 2001). Accordingly, the host mainly defines the work content and work environment (Liu et al., 2010; van Breugel et al., 2005). Given that job satisfaction reflects the discrepancy between what the host actually provides of work content and environment and what temps expect (Locke, 1969), and given that the psychological contract with the host incorporates all expectations regarding work content and environment that the temps perceives the host obligated to fulfil, a fulfilled psychological contract by the host should influence the temps' job satisfaction. Consequently, we hypothesise:

H1a. The relation between fulfilment of the psychological contract by the host and a temp's job satisfaction is positive.

Yet, the agency does not only fulfil administrative employer tasks, it also assigns temps to specific hosts and provides temps with multiple job offers and flexibility. Access to these services is the main advantage associated with temporary agency work (Liu et al., 2010; van Breugel et al., 2005). However, once the temp starts working for the host, the much of the agency's services have already been provided, and the non-content related aspects of the work (e.g. wage) are fixed. Thus, it is probable that temps have already evaluated to what extent the agency has met their expectations in terms of fulfilling the psychological contract by the time they start their assignment at the host.

Temps' evaluations of agency, done in a previous stage, might spill-over to the evaluation of the host, done at a later stage. Following the social balance theory, individuals who already maintain a good relationship with a first interaction partner tend to evaluate the second interaction partner more positively in order to create social balance (Cartwright and Harary, 1956; Heider, 1958). For example, a temp who 
perceives that the agency has fulfilled the psychological contract may then evaluate the agency as a fair and trustworthy partner, and is less likely to develop negative attitudes towards the host than a temp whose psychological contract is not fulfilled by the agency (Molm et al., 2007). Consequently, the evaluation of the psychological contract's fulfilment by the agency might influence the relationship between the fulfilment of the psychological contract by the host and the temps' job satisfaction. Therefore, we hypothisise:

H1b. Fulfilment of the psychological contract by the agency moderates the relationship between fulfilment of the psychological contract by the host and the temp's job satisfaction such that the relationship is stronger when the fulfilment of the psychological contract by the agency is high.

\section{Commitment}

Affective commitment is an attitude towards an organisation, its actions, and its objectives that reflect emotions and feelings of belonging to the organisation (Meyer and Allen, 1991). Attitudes towards an organisation are formed by experiences with an organisation. Hence, positive experience often results in positive attitudes towards the organisation and negative experiences result, in negative attitudes (Ajzen, 1991; Ajzen and Madden, 1986). An employee might perceive the fulfilment of a psychological contract by the employer as a positive experience. Therefore, a fulfilled psychological contract may positively affect the employee's commitment towards the employer (Zhao et al., 2007).

However, temps have two employers: the agency and the host, and research suggests that having simultaneous multiple foci of commitment are possible (Coyle-Shapiro et al, 2006; Gallagher and Parks, 2001; Guest, 2004; van Breugel et al., 2005). In particular, Barringer and Sturman (1998) and Liden et al. (2003) found that temps could be concurrently committed to both their agency and host. Given these findings, we argue that temps form simultaneous commitment towards their host and their agency. Moreover, we assume that a fulfilled psychological contract by the agency leads to a positive experience having been made with the agency, and therefore, leads to a temp's higher level of commitment towards the agency. Accordingly, a fulfilled psychological contract by the host might lead to a temp's higher level of commitment towards the host. Thus, we hypothsise:

H2a. The relation between fulfilment of the psychological contract by the host and a temp's commitment toward the host is positive.

H3a. The relation between fulfilment of the psychological contract by the agency and a temp's commitment toward the agency is positive. 
The agency and the host, however, do not act independently of each other. As a result of the placement process and coordination with the host, the agency influences how temps are integrated into the host (Liu et al., 2010). The temps also expect to be supported by the agency in case problems arise with the host, such as difficulties with their supervisor or co-workers (Druker and Stanworth, 2004; Liu et al., 2010). However, it is the host that has control over work conditions and reports the satisfaction with the temp to the agency (Gallagher and McLean Parks, 2001). Accordingly, temps, agencies, and hosts are a group made up of three interaction partners, influencing each other not only directly, but also indirectly. To contribute to or maintain group norms of reciprocity, individuals might evaluate exchange partners in indirect exchanges with more goodwill (Cartwright and Harary, 1958; Molm et al., 2007; Seinen and Schram, 2001). This assumption is consistent with findings in the field: Connelly et al. (2007) and Coyle-Shapiro et al. (2006) found positive correlations between temps' commitment towards the host and the agency. Other findings also indicate that in employees' commitment towards different agents, such as unions, the employer and the workgroup overlaps (Gallagher and Parks, 2001).

Accordingly, we assume that temps whose psychological contract is fulfilled by the agency, but not by the host, still have more commitment towards the host than temps whose psychological contract is not fulfilled by both organizations. In this respect, Connelly et al. (2007) and Liden et al. (2003) found evidence that the perceived support of the agency is related to commitment towards the host. The opposite is also likely: A temp whose psychological contract is fulfilled by the host but not by the agency should show more commitment towards the host compared to a temp whose psychological contract is not fulfilled by neither the agency nor the host. Thus, we hypothesise:

H2b. Fulfilment of the psychological contract by the agency moderates the relation between fulfilment of psychological contract by the host and a temp's commitment toward the host such that the relation is stronger when the fulfilment of the psychological contract by the agency is high.

H3b. Fulfilment of the psychological contract by the host moderates the relationship between fulfilment of the psychological contract by the agency and a temp's commitment toward the agency such that the relationship is stronger when the fulfilment of the psychological contract by the host is high.

\section{Intentions to stay with the agency}

According to Swiss law and many other federal laws, the validity of the legal employment contract between the temp and the agency is limited to the duration of the temp's assigment to the host (Swiss State Secretariat for Economic Affairs SECO, 2003). When workers are not assigned to a host, they are 
not formally employed by the agency, although they can still be registered at that agency in order to receive future assignments. However, registration alone does not impose any obligation on the agency or the temp (Swiss State Secretariat for Economic Affairs SECO, 2003). In this respect, the intentions to stay with the agency reflect whether or not temps plan to stay registered at the current agency and take up future assignments. These intentions are determined by the perceived service quality and service value of the agency, as well as by the temp's trust in the agency; that its actions will lead to positive outcomes for the temp (Cronin et al., 2000; Venetis and Ghauri, 2004).

A great body of research in the field of traditional workers' psychological contracts shows that an unfulfilled psychlogical contract may lead to mistrust (Zhao et al., 2007). For example, Robinson (1996) found that trust mediates the relation between psychological contract fulfillment and intentions to stay with the employer. Thus, we assume that an unfulfilled psychological contract by the agency reduces temps' trust in the agency, and therefore, reduces temps' intentions to stay with the agency. In addition, the agency provides temps with a varity of services including advising, placing, and supporting temps (Liu et al., 2010; van Breugel et al., 2005). Whether temps evaluate the quality of these services as satisfying or not depends on the degree to which the agency meets expectations that are important to the temp (Seth et al., 2005). As temps' psychological contract with the agency includes all the temps' expectations (Zhao et al., 2007), we assume that the fulfilment of the psychological contract by the agency affects temps' intentions to stay with the agency by affecting their valuation of service quality. Thus, we hypothesise:

H4a. The relation between the agency's fulfilment of the psychological contract and a temp's intentions to stay with the agency is positive.

Because temps expect agencies to act on their behalf when suggesting their services to hosts and to support their interests regarding the hosts (Druker and Stanworth, 2004; Liu et al., 2010), an indirect exchange between the temps, agencies, and hosts arises. As demonstrated previously, if individuals find themselves in a well working exchange triad, affective attachment to all exchange partners will increase (Molm et al., 2007; Seinen and Schram, 2001, Yamagishi and Cook, 1993). Temps do not evaluate their intentions to stay with the agency independently from the preceived relationship with the host. Thus, it appears that fullfilment of the psycholoical contract by the host moderates the relationship between fullfilment of the psychological contract by the agency and the intentions to stay with the agency. Therefore, we hypothesise:

H4b. Fulfilment of the psychological contract by the host moderates the relation between fulfilment of the psychological contract by the agency and a temp's intentions to stay with the agency such that the relation is stronger when the fulfilment of the psychological contract by the host is high. 


\section{Method}

\section{Procedure}

We collected data using an online survey in February 2010. The survey link was sent to 2,463 randomly selected German-speaking temps employed at a large agency in Switzerland that employs about 40,000 temps. This agency provides services to hosts from all industries and of all sizes. In Switzerland, in contrast to other European countries such as France or Germany, no restrictions exist pertaining to the use of temporary agency work in particular industries (Swiss State Secretariat for Economic Affairs SECO, 2008).

Four-hundred-thirteen participants completed the questionnaire, but 58 participants dropped out of the sample because they were registered at the agency but not assigned to a host at the time the survey was conducted. The low response rate of $16.8 \%$ indicates that non-response bias might exist. To examine this bias we conducted t-tests and compared the characteristics of early and late responders, in accordance with Armstrong and Overton (1977). We did not find significant differences between early and late responders, however, in light of this low response rate, this study should be considered explorative.

\section{Measures}

Our measures have been derived from previous studies of employees (with different forms of contracts) in Switzerland (Grote and Staffelbach, 2011; 2010). Moreover, we also performed an expert pre-test of the survey. Responses were rated on a six-point Likert scale ranging from 1 (not at all) to 6 (absolutely), unless otherwise noted.

We measured the fulfilment of the psychological contract with the agency and the host separately. For this we used the three-item scale developed by Tekleab and Taylor (2003). An example item is: "My agency / host did a good job in meeting my expectations."

Job satisfaction was measured with a single item, as proposed by Wanous et al. (1997). Participants answered how satisfied they were with their job in general.

Affective commitment towards the agency and towards the host was measured with four items from Allen and Meyer (1990). Respondents rated the extent to which they agreed to statements such as: "I feel emotionally attached to my agency / host."

Intentions to stay with the agency were measured with two items adapted from Cronin et al. (2000). This scale was developed to measure consumer behavioural intentions related to service providers in 
general. Our items were: "There is a high probability that I will use the services of the agency again"; "If I had to choose an agency again, I would make the same choice".

Scale scores were averaged across scale items to reflect the construct (i.e. a higher score reflects higher affective commitment). To calculate scores of multiple item scales when single item scores were missing, we used a robust procedure suggested by Roth et al. (1999) of averaging the scores only for responses that were available. Scores on multiple item scales were missing for those individuals who did not respond to any items of a particular scale. Because fewer participants are excluded from the analyses, the chosen procedure might better preserve information than considering a scale score with any scale item missing as missing in total (Roth et al., 1999). However, to ensure that our procedure of handling missing scale items did not bias results, we also estimated the models by excluding all participants for that data of any single item was missing. We found no substantial differences in results.

Individual difference variables were also asked including gender $(1=$ male, $0=$ female $)$, age in years, employment $(1=$ part-time; 0 = full-time $)$, and education $(1=$ high education compromising higher vocational education, bachelor, master and above, $0=$ low education compromising compulsory school, apprenticeship/vocational and high school). Of note, "higher vocational education" is also considered well-educated in the Swiss context. Moreover, previous research found that temps' commitment to the agency is positively related to previous assignments at the agency (Guest, 2004), thus, we controlled for previous assignments ( $1=$ at least one previous assignment; $0=$ no previous assignments).

Being temporary employed voluntarily has also been found to have influence temps' job attitudes (de Cuyper et al., 2008; McLean Parks et al., 1998). To control for voluntariness, we adapted an item from Ellingson et al. (1998): "I prefer temporary agency work over permanent work." However, 10.2\% did not respond to this variable, which was high, especially compared to other variables (see Table 1). Given this high amount of missing data and the sensitive nature of the item, it seems that missings were not random. Thus, to avoid a potential bias in our analyses, we did not include the variable voluntariness.

\section{Sample}

After data cleaning, our sample consisted of 352 temps. The average age was 33.14 years $(\mathrm{SD}=11.29)$. Twenty-seven per cent had a high education level, $32 \%$ were employed part-time, and $45 \%$ were male. Fifty-four per cent had been previously assigned at the agency.

\section{Analysis}

Scale reliability and correlation coefficients among all variables were obtained in preliminary analysis. To test our hypotheses, we followed Baron and Kenny (1986) in estimating moderated regressions. In model 1, the control variables were introduced. In model 2, fulfilment of the psychological contract by the agency and fulfilment of the psychological contract by the host were added. In model 3 , the two- 
way interaction term of the psychological contract fulfilments was entered. To avoid problems with multicollinearity, we followed Cohen (2003) by centring the predictors' scores prior to the computation of the interaction term. Moreover, we calculated VIF scores. Scores above 10.0 would imply that multicollinearity is likely (Meyers, 1990). Our highest VIF score was 1.45.

To calculate effect sizes, we used bootstrapping, a resampling technique that does not require distributional assumptions (Efron \& Tibshirani, 1993). We considered bootstrapping as appropriate as our outcome variables did not follow a normal distribution. When the sample size is small, as our sample size is $(\mathrm{N}=352)$, bias-corrected and accelerated bootstrapping (BCa Bootstrap) provides more accurate confidence intervals than traditional bootstrap techniques and adjusts for both, bias and skewness in the bootstrap distribution (Good, 2001; Preacher \& Hayes, 2008). Specifically, we applied BCa Bootstrap method with 10,000 bootstrap samples and estimated the $95 \%$ confidence intervals $(C I)$.

Furthermore, because our self-reported data might be biased by common method variance, we followed the suggestion of Podsakoff et al. (2003) and performed Herman's single-factor tests for all regressions. These tests suggest that common method variance does not bias our results. Moreover, we conducted a MCAR-test to investigate whether missings follow non-random patterns (Little, 1988). The test was non-significant $(\chi 2=125.06, \mathrm{df}=113, p=.21)$. In the estimated models, missing data were list-wise deleted, meaning that we excluded individuals from analyses unless all scores on scale items were known.

\section{Results}

\section{Preliminary analysis}

Table 1 shows the reliabilities of the scales and the correlations and the means and standard deviations among the core variables. Fulfilment of the psychological contract with the agency was positively correlated with all dependent variables: job satisfaction $(\mathrm{r}=.40, p<.01)$, commitment towards the host $(\mathrm{r}=.31, p<.01)$, commitment towards the agency $(\mathrm{r}=.51, p<.01)$ and intentions to stay with the agency $(\mathrm{r}=.76, p<.01)$. Also, fulfilment of the psychological contract with the host was positively correlated with all dependent variables: job satisfaction $(\mathrm{r}=.69, p<.01)$, commitment towards the host $(\mathrm{r}=.61, p<.01)$, commitment towards the agency $(\mathrm{r}=.25, p<.01)$, and intentions to stay with the agency $(\mathrm{r}=.42, p<.01)$. All Cronbach's alpha coefficients for the multiple item scales exceed .70 , indicating acceptable scale reliability. 


\section{Moderated regression analysis}

Results of the regression analysis for job satisfaction appear in Table 2, for commitment towards the host in Table 3, for commitment towards the agency in Table 4, and for intentions to stay with the agency in Table 5.

Firstly, model 3 best predicted job satisfaction (adj. $\left.\mathrm{R}^{2}=.50 ; \Delta \mathrm{R}^{2}=.01, p<.01\right)$. Psychological contract fulfilment by the host under model 3 also had a significant positive effect ( $\beta=0.75, C I=0.65$ to 0.85 ). Thus, hypothesis 1a is supported. In addition, we found a significant positive effect of the fulfilment of the psychological contract by the agency $(\beta=0.14, C I=0.02$ to 0.26$)$. The effect of the interaction term was also significant $(\beta=0.09, C I=0.01$ to 0.17 ), supporting hypothesis $1 \mathrm{~b}$. Figure 2 shows the interaction effects that a low fulfilment of the psychological contract by the agency and a high fulfilment of the psychological contract by the agency had on the average temp's job satisfaction.

\section{Table 2}

Figure 2

Secondly, model 2 best predicted commitment to the host $\left(\operatorname{adj} . \mathrm{R}^{2}=.38 ; \Delta \mathrm{R}^{2}=.37, p<.001\right)$. Under model 2, fulfilment of the psychological contract by the host had a positive, significant impact on commitment towards the host ( $\beta=0.67, C I=0.56$ to 0.77 ), supporting hypothesis $2 \mathrm{a}$. In contrast, the effect of the interaction term in model 3 was not significant $\left(\beta=0.04, n . s\right.$.), and model 3 (adj. $\mathrm{R}^{2}=.38$; $\left.\Delta \mathrm{R}^{2}=.00, n . s\right)$ did not predict commitment towards the host significantly better than model 2 . Thus, hypothesis $2 b$ is not supported.

\section{Table 3}

Thirdly, model 3 best predicted commitment towards the agency best $\left(\operatorname{adj} . \mathrm{R}^{2}=.37\right)$, and the increase in prediction power of model 3 compared to model 2 was significant $\left(\Delta \mathrm{R}^{2}=.01, p<.05\right)$. Under model 
3, fulfilment of the psychological contract by the agency had a positive effect $(\beta=0.68, C I=0.57$ to 0.80). Thus, hypothesis $3 \mathrm{a}$ is supported. Furthermore, the interaction term also showed a significant effect ( $\beta=0.10, C I=0.02$ to 0.18 ), supporting hypothesis $3 \mathrm{~b}$ (see Figure 3 ).

\section{Table 4}

\section{Figure 3}

Fourthly, model 2 best predicted intentions to stay with the agency (adj. $\left.\mathrm{R}^{2}=.59, \Delta \mathrm{R}^{2}=.56, p<.001\right)$. Model 2 indicates that the fulfilment of the psychological contract by the agency significant influences intentions to stay with the agency ( $\beta=0.79, C I=0.68$ to 0.89 ). Thus, hypothesis $4 \mathrm{a}$ is supported. However, in model 3, a significant positive effect of the interaction term was not found ( $\beta=-0.01$, n.s.). In addition, model 3 (adj. $\left.\mathrm{R}^{2}=.60 ; \Delta \mathrm{R}^{2}=.00, n . s\right)$ did not predict intentions to stay with the agency significantly better than model 2 . Thus, hypothesis $4 \mathrm{~b}$ is not supported.

\section{Table 5}

\section{Discussion}

Our study finds that, in general, fulfilment of the psychological contract positively relates to temps' job attitudes. This is in accordance with previous study of traditional workers (Conway and Briner, 2005). In particular, fulfilment of the psychological contract by the host is positively related to temps' job satisfaction and their commitment towards the host. Furthermore, our findings indicate that the higher the fulfilment of the psychological contract by the agency is, the higher the temps' commitment towards the agency and their intentions to stay with the agency. 
Moreover, our data indicates that fulfilment of the psychological contracts by the agency moderates temps' job satisfaction. In addition, commitment towards the agency is moderated by the fulfilment of the psychological contract by the host. In contrast, the fulfilment of the psychological by the agency as a moderator of the relation between fulfilment of the psychological contract by the host and the temps' commitment towards the host is not supported. These findings indicate that temps' commitment towards the host seems to be more stable or less influenced by the actions of the agency. The host's actions, however, seem to influence commitment towards the agency. The reason for this might lie in the agency's intermediate role. For example, Druker and Stanworth (2004) found, "the agency was trusted by most of the participants, to provide support if it was needed - and was seen as a 'go-between' supporting temps' interests in relation to client pressures" (p. 73). Thus, in order to be committed to the agency, whether or not the agency acts on their behalf if there are problems with the host seems to be important for temps. In other words, in the triangular employee-employer relationship, temps might hold the agency accountable for enforcing a balanced relationship between the temp and the host, thus, ensuring that the host fulfils its psychological contract with the temp. In contrast, temps might not assign a disciplinary role to the host. A possible explanation for this is that the agency is mainly responsible for aspects of work (e.g. wages; Gallagher and Parks, 2001), which the temp and the agency have already agreed upon once the temp starts working for the host, and the host has little option to change this.

Moreover, although the hosts' fulfilment of the psychological contract moderates temps' commitment towards the agency, intentions to stay with the agency is statistically unaffected by the hosts' fulfilment of the psychological contract. The commitment towards the agency is an emotional feeling of belonging (Meyer and Allen, 1991). Intentions to stay with the agency, on the other hand, refer to calculative longterm considerations (Jones and Sasser, 1995). In accordance with this, Liu et al. (2010) suggest that intentions to stay with the agency depend strongly on the perceived service value of the agency in the long term. It is the agency that is the temps' stable partner in the triangular employee-employerrelationship between the temps, the agency and the hosts. The hosts, however, might change. Thus, temps might evaluate further benefits of staying at the agency by considering prior experience with the agency (Seinen and Schram, 2001), not the hosts. As a result, temps may only assess the fulfilment of the psychological contract by the agency when evaluating whether or not to maintain a long-term relation with the agency.

For further insight into the quality and quantity of costs caused by unfulfilled psychological contracts, we would need to know what temps expect from the host and the agency. However, the contents of the temps' psychological contract with their agency and host are understudied (Claes, 2005; Guest, 2004); thus, further research is needed. In addition, with a response rate of $16.8 \%$, our study should be considered explorative. To validate findings and increase generalisability, further research with larger and more representative samples is recommended. Other limitations must also be considered. Firstly, because our study was cross-sectional, conclusions about causality cannot be drawn. Secondly, although 
our comparison of early and late responders did not provide reason for concern about a non-response bias, the risk of such a bias cannot be completely excluded. For example, it might be that temps with access to a computer at work were more willing to participate in the online-survey than temps without access. Thirdly, although self-reported and same-source data is often used to measure the fulfilment of the psychological contract and job attitude (e.g. Conway and Briner, 2005; Cullinane and Dundon, 2006), the risks of a common method bias still exist. However, the results of Herman's single-factor tests were not alarming in this study. Forth, because of a high amount of missing data, we did not control for voluntariness of temporary agency work. We assume that the high number of missings for this item was influenced by the sensitive nature of question. Thus, an avenue for further research could be to examine and improve existing measurements of voluntariness.

Aside from these limitations, our study contributes to the literature of the psychological contract in the context of multiple employers. Even though the possibility that the fulfilment of the psychological contract by one organisation will affect the job attitudes towards the other organisation has been discussed by psychological contract researchers, only a few studies have investigated these spill-overeffects empirically (e.g. Cullinane and Dundon, 2006; Guest, 2004; Marks, 2001). Indeed, our data indicates that one-sided spill-over effects do exist among temps. Further research might explore the causes and consequences of these interdependent effects more deeply. 


\section{References}

Ajzen, I. (1991), "The theory of planned behavior", Organizational Behavior and Human Decision Processes, Vol. 50 No. 2, pp. 179-211.

Ajzen, I. and Madden, T.J. (1986), "Prediction of goal-directed behavior: attitudes, intentions, and perceived behavioral control”, Journal of Experimental Social Psychology, Vol. 22 No. 5, pp. $453-474$.

Allen, N.J. and Meyer, J.P. (1990), "The measurement and antecedents of affective, continuance and normative commitment to the organization”, Journal of Occupational Psychology, Vol. 63, pp. 118.

Armstrong J.S. and Overton T. (1977), “Estimating nonresponse bias in mail surveys”, Journal of Marketing Research, Vol .14, pp. 396-402

Baron, R.M. and Kenny, D.A. (1986), "The moderator-mediator variable distinction in social psychological research: Conceptual, strategic, and statistical considerations, Vol. 51 No. 6, pp. $1173-1182$.

Blau, P.M. (1967), Exchange and Power in Social Life, Wiley, New York.

Barringer, M.W. and Sturman, M.C. (1998), "The effects of variable work arrangements on the organizational commitment of contingent workers", working paper No. 98-02, Cornell University, School of Industrial and Labor Relations, Center for Advanced Human Resource Studies, Ithaca, February.

Burgess, J. and Connel, J. (2006), "Temporary work and human resource management: issues, challenges and responses", Personnel Review, Vol. 35 No. 2, pp. 129-140.

Cartwright, D. and Harary, F. (1956), “Structural Balance: A Generalization of Heider's Theory”, The Psychological Review, Vol. 63 No.5, 277-293.

Claes, R. (2005), “Organization promises in the triangular psychological contract as perceived by temporary agency workers, agencies, and client organizations", Employee Responsibilities and Rights Journal, Vol. 17 No. 3, pp. 131-142.

Cohen, J. (2003), Applied multiple regression/correlation analysis for the behavioral sciences," Erlbaum Associates, Mahwah.

Connelly, C.E., Gallagher, D.G. and Gilley, K.M. (2007), “Organizational and client commitment among contracted employees: a replication and extension with temporary workers", Journal of Vocational Behavior, Vol. 70 No. 2, pp. 326-335.

Conway, N. and Briner, R.B. (2005), Understanding psychological contracts at work: A critical evaluation of theory and research, Oxford University Press, Oxford ; New York. 
Coyle-Shapiro, J.A.-M., Morrow, P.C. and Kessler, I. (2006), "Serving two organizations: exploring the employment relationship of contracted employees", Human Resource Management, Vol. 45 No. 4, pp. 561-583.

Cronin, J.J., JR., Brady, M.K. and Hult, G.T.M. (2000), “Assessing the effects of quality, value, and customer satisfaction on consumer behavioral intentions in service environments", Journal of Retailing, Vol. 76 No. 2, pp. 193-218.

Cullinane, N. and Dundon, T. (2006), "The psychological contract: a critical review", International Journal of Management Reviews, Vol. 8 No. 2, pp. 113-129.

de Cuyper, N., Jong, J. de, Witte, H. de, Isaksson, K., Rigotti, T. and Schalk, R. (2008), “Literature review of theory and research on the psychological impact of temporary employment: towards a conceptual model", International Journal of Management Reviews, Vol. 10 No. 1, pp. 25-51.

Druker, J. and Stanworth, C. (2004), "Mutual expectations: a study of the three-way relationship between employment agencies, their client organisations and white-collar agency 'temps'”, Industrial Relations Journal, Vol. 35 No. 1, pp. 58-75.

Efron, B. and Tibshirani R.J. (1993). An introduction to the bootstrap, Chapman \& Hall, New York.

Ellingson, J.E., Gruys, M.L. and Sackett, P.R. (1998), "Factors related to the satisfaction and performance of temporary employees", Journal of Applied Psychology, Vol. 83 No. 6, pp. 913921.

Gallagher, D.G. and Parks, J.M. (2001), "I pledge thee my troth...contingently: commitment and the contingent work relationship", Human Resource Management Review, Vol. 11 No. 3, pp. 181201.

Good, P. (2001), Resampling methods: A practical guide to data analysis, Springer, New York.

Grote, G. and Staffelbach, B. (2011), Schweizer HR-Barometer 2011: Unsicherheit und Vertrauen, NZZ Libro, Zürich.

Grote, G. and Staffelbach, B. (2010), Schweizer HR-Barometer 2010:Arbeitsflexibilität und Familie, NZZ Libro, Zürich.

Guest, D. (1998), "Is the psychological contract worth taking seriously?", Journal of Organizational Behavior, Vol. 19 No. 1, pp. 649-664.

Guest, D. (2004), "Flexible employment contracts, the psychological contract and employee outcomes: an analysis and review of the evidence", International Journal of Management Reviews, Vol. 5-6 No. 1, pp. 1-19.

Heider, F. (1958), The Psychology of Interpersonal Relations, Wiley, New York. 
Jones, T.O. and Sasser, W.E., JR. (1995), "Why satisfied customers defect”, Harvard Business Review, Vol. 73 No. 6, pp. 88-91.

Judge, T.A., Thoresen, C.J., Bono, J.E. and Patton, G.K. (2001), “The job satisfaction-job performance relationship: a qualitative and quantitative review", Psychological Bulletin, Vol. 127 No. 3, pp. 376-407.

Liden, R.C., Wayne, S.J., Kraimer, M.L. and Sparrowe, R.T. (2003), "The dual commitments of contingent workers: an examination of contingents' commitment to the agency and the organization", Journal of Organizational Behavior, Vol. 24 No. 5, pp. 609-625.

Little , R.J.A. (1988), "A Test of Missing Completely at Random for Multivariate Data With Missing Values", Journal of the American Statistical Association, Vol. 83 No. 404, pp. 1198-1202.

Liu, C.-T., Wu, C. and Hu, C.-W. (2010), "Managing temporary workers by defining temporary work agency service quality”, Human Resource Management, Vol. 49 No. 4, pp. 619-646.

Locke, E. (1969), “What is job satisfaction?”, Organizational behavior and human performance, Vol. 4 No. 4, pp. 309-336.

Marks, A. (2001), "Developing a multiple foci conceptualization of the psychological contract", Employee Relations, Vol. 23 No. 5, pp. 454-469.

McLean Parks, J., Kidder, D.L. and Gallagher, D.G. (1998), "Fitting square pegs into round holes: mapping the domain of contingent work arrangements onto the psychological contract", Journal of Organizational Behavior, Vol. 19 No. 1, pp. 697-730.

Meyers, R. (1990), Classical and modern regression with applications, Duxbury, Boston.

Meyer, J.P. and Allen, N.J. (1991), “A three component conceptualization of organizational commitment”, Human Resource Management Review, Vol. 1 No. 1, pp. 61-89.

Meyer, J.P., Paunonen, S.V., Gellatly, I.R., Goffin, R.D. and Jackson, D.N. (1989), “Organizational commitment and job performance: it's the nature of the commitment that counts", Journal of Applied Psychology, Vol. 74 No. 1, pp. 152-156.

Molm, L.D., Collet, J.L. and Schaefer, D.R. (2007), "Building Solidarity through Generalized Exchange: A Theory of Reciprocity", American Journal of Sociology, Vol. 113 No. 1, pp. $203-$ 242.

Mueller, C.W. and Lawler, E.J. (1999), "Commitment to nested organizational units: some basic principles and preliminary findings", Social Psychology Quarterly, Vol. 62 No. 4, pp. 325-346.

Preacher, K.J. and Hayes, A.F. (2008), “Asymptotic and resampling strategies for assessing and comparing indirect effects in multiple mediator models", Behavior research methods, Vo. 40 No. 3, pp. 879-891. 
Podsakoff, P. M., MacKenzie, S. B., Lee, J.-Y. and Podsakoff, N. P. (2003), “Common method biases in behavioral research: A critical review of the literature and recommended remedies", Journal of Applied Psychology, Vol. 88 No. 5, pp. 879-903.

Robinson, S.L. (1996), „Trust and Breach of the Psychological Contract“, Administrative Science Quarterly, Vol. 41, pp. 574-599.

Rosinger, M. and Djurdjevic, D. (2007), “Temporärarbeit in der Schweiz: Motive und Arbeitsmarktperspektiven", Die Volkswirtschaft, Vol. 4, pp. 47-50.

Roth, P.L., Switzer, F.S. and Switzer, D.M. (1999), "Missing data in multiple item scales: A Monte Carlo analysis of missing data techniques”, Organizational Research Methods, Vol. 2 No. 3, pp. 211-232.

Rousseau, D.M. (1995), Psychological contracts in organizations: understanding written and unwritten agreements, SAGE Publications, Thousand Oaks.

Saari, L.M. and Judge, T.A. (2004), "Employee attitudes and job satisfaction”, Human Resource Management, Vol. 43 No. 4, pp. 395-407.

Seinen, I. and Schram, A. (2006), "Social Status and Group Norms: Indirect Reciprocity in a Helping Experiment", European economic review, Vol. 50 No.3, pp. 581-602.

Seth, N., Deshmukh, S. and Vrat, P. (2005), “Service quality models: a review”, International Journal of Quality \& Reliability Management, Vol. 22 No. 9, pp. 913-949.

Spector, P.E. (1997), Job satisfaction: application, assessment, cause, and consequences, SAGE Publications, Thousand Oaks.

Svensson, S. and Wolvén, L.-E. (2010), "Temporary agency workers and their psychological contracts", Employee Relations, Vol. 32 No. 2, pp. 184-199.

Swiss State Secretariat for Economic Affairs [SECO] (2003), "Merkblatt zu den Bestimmungen über den Personalverleih gemäss Bundesgesetz über die Arbeitsvermittlung und den Personalverleih (AVG) vom 6. Oktober 1989”, available at: www.seco.admin.ch/dokumentation/publikation/ 00009/00027/01827/index.html?download=NHzLpZeg7t,lnp6I0NTU04212Z61n1acy4Zn4Z2qZpn O2Yuq2Z6gpJCDfH16fGym162epYbg2c_JjKbNoKSn6A--\&lang=de (accessed 24 September 2012).

Swiss State Secretariat for Economic Affairs [SECO](2008), "Überprüfung der heutigen Situation im Bereich des Personalverleihs (Arbeitsvermittlungsgesetz, AVG)", available at: http://www.news.admin.ch/NSBSubscriber/message/attachments/14550.pdf (accessed 24 September 2012). 
Tekleab, A.G. and Taylor, M.S. (2003), “Aren't there two parties in an employment relationship? antecedents and consequences of organization-employee agreement on contract obligations and violations", Journal of Organizational Behavior, Vol. 24 No. 5, pp. 585-608.

van Breugel, G., van Olffen, W. and Olie, R. (2005), “Temporary liaisons: the commitment of 'temps' towards their agencies", Journal of Management Studies, Vol. 42 No. 3, pp. 539-566.

Venetis, K.A. and Ghauri, P.N. (2004), “Service quality and customer retention: building long-term relationships", European Journal of Marketing, Vol. 38 No. 11/12, pp. 1577-1598.

Wanous, J.P., Reichers, A.E. and Hudy, M.J. (1997), "Overall Job Satisfaction: how good are singleitem mesures?", Journal of Applied Psychology, Vol. 82 No. 2, pp. 247-252.

Yamagishi, T. and Cook, K.S. (1993), "Generalized Exchange and Social Dilemmas”, Social Psychological Quarterly, Vol 56 No. 4, pp. 235-258.

Zhao, H.A., Wayne, S.J., Glibowski, B.C. and Bravo, J. (2007), "The impact of psychological contract breach on work-related outcomes: a meta-analysis", Personnel Psychology, Vol. 60 No. 3, pp. $647-680$. 


\section{TABLES}

\section{The double psychological contracts of temporary agency workers}

Table 1: $\quad$ Means, standard deviations, missing data, Cronbach's Alpha Reliabilities (in the diagonal) and correlations

\begin{tabular}{|c|c|c|c|c|c|c|c|c|c|c|c|}
\hline & 1 & 2 & 3 & 4 & 5 & 6 & 7 & 8 & 9 & 10 & 11 \\
\hline \multicolumn{12}{|l|}{1 Job satisfaction } \\
\hline 2 Commitment host & $.678^{* *}$ & $(.93)$ & & & & & & & & & \\
\hline 4 Intentions stay agency & $.304^{* *}$ & $.289^{* *}$ & $.585^{* *}$ & $(.88)$ & & & & & & & \\
\hline 5 Fulfilment PC agency & $.396^{* *}$ & $.310^{* *}$ & $.510^{* *}$ & $.756^{* *}$ & (.87) & & & & & & \\
\hline 8 Gender & -.031 & .053 & .019 & -.059 & $-.126^{*}$ & -.076 & $-124^{*}$ & & & & \\
\hline 9 Education & -.025 & -.071 & $-.248^{* *}$ & $-.140^{* *}$ & $-.140^{* *}$ & -.056 & $.156^{* *}$ & $-.109^{*}$ & & & \\
\hline 10 Employment & .004 & -.041 & -.104 & .000 & .075 & -017 & .030 & $-.250^{* *}$ & -.090 & & \\
\hline 11 Previous assignment & -.064 & -.098 & $.125^{*}$ & .080 & -.057 & -.069 & $.152^{* *}$ & $.146^{* *}$ & -.052 & .099 & \\
\hline
\end{tabular}

Note: $\mathrm{N}=352$. Significance levels: $* \mathrm{p}<.05 ; * * \mathrm{p}<.01 ; \mathrm{PC}=$ psychological contract; Gender: $1=$ male, $0=$ female; Education: $1=$ high education, $0=$ low education; Employment: $1=$ part-time, $0=$ full-time; Previous Assignment: $1=$ yes, $0=$ no. 


\section{THE DOUBLE PSYCHOLOGICAL CONTRACTS}

Table 2: $\quad$ Moderated regression analysis for job satisfaction

\begin{tabular}{|c|c|c|c|c|c|c|c|c|c|}
\hline \multirow[t]{3}{*}{ Steps and Variables } & \multicolumn{3}{|c|}{ Model 1} & \multicolumn{3}{|c|}{ Model 2} & \multicolumn{3}{|c|}{ Model 3} \\
\hline & \multirow[t]{2}{*}{$\beta$} & \multicolumn{2}{|c|}{$\begin{array}{c}95 \% \text { BCa CIs } \\
\text { (bootstrap results) }\end{array}$} & \multirow[t]{2}{*}{$\beta$} & \multicolumn{2}{|c|}{$\begin{array}{c}95 \% \text { BCa CIs } \\
\text { (bootstrap results) }\end{array}$} & \multirow[t]{2}{*}{$\beta$} & \multicolumn{2}{|c|}{$\begin{array}{c}95 \% \text { BCa CIs } \\
\text { (bootstrap results) }\end{array}$} \\
\hline & & Lower & Upper & & Lower & Upper & & Lower & Upper \\
\hline Intercept & $4.76^{* * *}$ & 4.29 & 5.23 & 0.56 & -0.24 & 1.35 & 0.16 & -0.53 & 0.81 \\
\hline Age & 0.00 & -0.01 & 0.01 & 0.01 & 0.00 & 0.02 & 0.01 & 0.00 & 0.02 \\
\hline Gender $(1=$ male $)$ & -0.05 & -0.36 & 0.25 & 0.12 & -0.09 & 0.32 & 0.08 & -0.12 & 0.29 \\
\hline Education (1=high) & -0.12 & -0.46 & 0.21 & 0.04 & -0.19 & 0.28 & 0.07 & -0.17 & 0.32 \\
\hline Employment (1=part-time) & 0.03 & -0.30 & 0.36 & 0.07 & -0.15 & 0.29 & 0.07 & -0.15 & 0.30 \\
\hline Previous assignment ( $1=$ yes) & -0.15 & -0.43 & 0.14 & -0.07 & -0.27 & 0.15 & -0.08 & -0.28 & 0.14 \\
\hline Fulfilment PC agency & & & & 0.11 & -0.02 & 0.23 & $0.14^{*}$ & 0.02 & 0.26 \\
\hline Fulfilment PC host & & & & $0.72^{* * *}$ & 0.61 & 0.83 & $0.75^{* * *}$ & 0.65 & 0.85 \\
\hline \multicolumn{10}{|l|}{ Fulfilment PC agency X } \\
\hline Fulfilment PC host & & & & & & & $0.09^{*}$ & 0.01 & 0.17 \\
\hline Adjusted R2 & .00 & & & .48 & & & .50 & & \\
\hline$\Delta \mathrm{R} 2$ Change & .01 & & & $.49^{* * *}$ & & & $.01^{* *}$ & & \\
\hline F-statistic & 0.34 & & & 46.52 & & & 43.08 & & \\
\hline$\Delta$ F-statistic & 0.34 & & & 161.19 & & & 10.13 & & \\
\hline
\end{tabular}

Note: $\mathrm{N}=342$. Unstandardised regression coefficients are shown. Significance levels: $* \mathrm{p}<.05 ; * * \mathrm{p}<.01 ; * * * \mathrm{p}<.001 . \mathrm{PC}=$ psychological contract. 
Table 3: $\quad$ Moderated regression analysis for commitment towards the host

\begin{tabular}{|c|c|c|c|c|c|c|c|c|c|}
\hline \multirow[t]{3}{*}{ Steps and Variables } & \multicolumn{3}{|c|}{ Model 1} & \multicolumn{3}{|c|}{ Model 2} & \multicolumn{3}{|c|}{ Model 3} \\
\hline & \multirow[t]{2}{*}{$\beta$} & \multicolumn{2}{|c|}{$\begin{array}{c}95 \% \text { BCa CIs } \\
\text { (bootstrap results) }\end{array}$} & \multirow[t]{2}{*}{$\beta$} & \multicolumn{2}{|c|}{$\begin{array}{c}95 \% \text { BCa CIs } \\
\text { (bootstrap results) }\end{array}$} & \multirow[t]{2}{*}{$\beta$} & \multicolumn{2}{|c|}{$\begin{array}{c}95 \% \text { BCa CIs } \\
\text { (bootstrap results) }\end{array}$} \\
\hline & & Lower & Upper & & Lower & Upper & & Lower & Upper \\
\hline Intercept & $4.17^{* * *}$ & 3.71 & 4.64 & 0.54 & -0.19 & 1.24 & 0.38 & -0.35 & 1.09 \\
\hline Age & 0.01 & -0.01 & 0.02 & $0.01^{*}$ & 0.00 & 0.02 & $0.01^{*}$ & 0.00 & 0.02 \\
\hline Gender $(1=$ male $)$ & 0.17 & -0.15 & 0.49 & $0.30^{*}$ & -0.07 & 0.54 & $0.29^{*}$ & 0.06 & 0.53 \\
\hline Previous assignment (1=yes) & $-0.31^{*}$ & -0.61 & -0.01 & -0.23 & -0.47 & 0.01 & -0.23 & -0.47 & 0.01 \\
\hline Fulfilment PC agency & & & & 0.05 & -0.06 & 0.16 & 0.06 & -0.05 & 0.18 \\
\hline Fulfilment PC host & & & & $0.67^{* * *}$ & 0.56 & 0.77 & $0.68^{* * *}$ & 0.57 & 0.78 \\
\hline \multicolumn{10}{|l|}{ Fulfilment PC agency $\mathrm{X}$} \\
\hline Adjusted R2 & .01 & & & .38 & & & .38 & & \\
\hline$\Delta \mathrm{R} 2$ Change & .02 & & & $.37^{* * *}$ & & & .00 & & \\
\hline F-statistic & 1.59 & & & 30.74 & & & 27.06 & & \\
\hline$\Delta$ F-statistic & 1.59 & & & 101.21 & & & 1.19 & & \\
\hline
\end{tabular}

Note: $\mathrm{N}=338$. Unstandardised regression coefficients are shown. Significance levels: $* \mathrm{p}<.05 ; * * \mathrm{p}<.01 ; * * * \mathrm{p}<.001 . \mathrm{PC}=$ psychological contract. 
THE DOUBLE PSYCHOLOGICAL CONTRACTS

Table 4: $\quad$ Moderated regression analysis for commitment towards the agency

\begin{tabular}{|c|c|c|c|c|c|c|c|c|c|}
\hline \multirow[t]{3}{*}{ Steps and Variables } & \multicolumn{3}{|c|}{ Model 1} & \multicolumn{3}{|c|}{ Model 2} & \multicolumn{3}{|c|}{ Model 3} \\
\hline & \multirow[t]{2}{*}{$\beta$} & \multicolumn{2}{|c|}{$\begin{array}{c}95 \% \text { BCa CIs } \\
\text { (bootstrap results) }\end{array}$} & \multirow[t]{2}{*}{$\beta$} & \multicolumn{2}{|c|}{$\begin{array}{c}95 \% \text { BCa CIs } \\
\text { (bootstrap results) }\end{array}$} & \multirow[t]{2}{*}{$\beta$} & \multicolumn{2}{|c|}{$\begin{array}{c}95 \% \text { BCa CIs } \\
\text { (bootstrap results) }\end{array}$} \\
\hline & & Lower & Upper & & Lower & Upper & & Lower & Upper \\
\hline Intercept & $3.04^{* * *}$ & 2.53 & 3.53 & -0.42 & -1.20 & 0.35 & -0.84 & -1.65 & -0.01 \\
\hline Age & $0.02^{* *}$ & 0.01 & 0.03 & $0.02^{* * *}$ & 0.01 & 0.04 & $0.02^{* * *}$ & 0.01 & 0.04 \\
\hline Gender $(1=$ male $)$ & -0.21 & -0.55 & 0.14 & 0.00 & -0.29 & 0.29 & -0.03 & -0.32 & 0.25 \\
\hline Education (1=high) & $-0.92^{* * *}$ & -1.26 & -0.58 & $-0.65^{* * *}$ & -0.95 & -0.36 & $-0.63^{* * *}$ & -0.93 & -0.33 \\
\hline Employment (1=part-time) & -0.32 & -0.67 & 0.05 & $-0.42^{*}$ & -0.75 & -0.10 & $-0.42^{*}$ & -0.73 & -0.10 \\
\hline Previous assignment ( $1=$ yes $)$ & $0.35^{*}$ & 0.02 & 0.67 & $0.43^{* *}$ & 0.16 & 0.69 & $0.42^{* *}$ & 0.15 & 0.68 \\
\hline Fulfilment $\mathrm{PC}$ agency & & & & $0.65^{* * *}$ & 0.53 & 0.76 & $0.68^{* * *}$ & 0.57 & 0.80 \\
\hline Fulfilment PC host & & & & 0.02 & -0.11 & 0.15 & 0.06 & -0.08 & 0.20 \\
\hline \multicolumn{10}{|l|}{ Fulfilment PC agency X } \\
\hline Fulfilment PC host & & & & & & & $0.10^{* *}$ & 0.02 & 0.18 \\
\hline Adjusted R2 & .09 & & & .36 & & & .37 & & \\
\hline$\Delta \mathrm{R} 2$ Change & $.10^{* * *}$ & & & $.27^{* * *}$ & & & $.01^{*}$ & & \\
\hline F-statistic & 7.65 & & & 28.01 & & & 25.70 & & \\
\hline$\Delta$ F-statistic & 7.65 & & & 70.95 & & & 6.38 & & \\
\hline
\end{tabular}

Note: $\mathrm{N}=341$. Unstandardised regression coefficients are shown. Significance levels: $* \mathrm{p}<.05 ; * * \mathrm{p}<.01 ; * * * \mathrm{p}<.001 . \mathrm{PC}=$ psychological contract. 
THE DOUBLE PSYCHOLOGICAL CONTRACTS

Table 5: $\quad$ Results of moderated regression analysis for intentions to stay with the agency

\begin{tabular}{|c|c|c|c|c|c|c|c|c|c|}
\hline \multirow[t]{3}{*}{ Steps and Variables } & \multicolumn{3}{|c|}{ Model 1} & \multicolumn{3}{|c|}{ Model 2} & \multicolumn{3}{|c|}{ Model 3} \\
\hline & \multirow[t]{2}{*}{$\beta$} & \multicolumn{2}{|c|}{$\begin{array}{c}95 \% \text { BCa CIs } \\
\text { (bootstrap results) }\end{array}$} & \multirow[t]{2}{*}{$\beta$} & \multicolumn{2}{|c|}{$\begin{array}{c}95 \% \text { BCa CIs } \\
\text { (bootstrap results) }\end{array}$} & \multirow[t]{2}{*}{$\beta$} & \multicolumn{2}{|c|}{$\begin{array}{c}95 \% \text { BCa CIs } \\
\text { (bootstrap results) }\end{array}$} \\
\hline & & Lower & Upper & & Lower & Upper & & Lower & Upper \\
\hline Intercept & $5.14^{* * *}$ & 4.69 & 5.58 & $0.74^{*}$ & 0.07 & 1.38 & $0.77^{*}$ & 0.13 & 1.38 \\
\hline Age & -0.01 & -0.02 & 0.01 & 0.00 & -0.01 & 0.01 & 0.00 & -0.01 & 0.01 \\
\hline Gender $(1=$ male $)$ & -0.26 & -0.58 & 0.06 & -0.01 & -0.20 & 0.19 & 0.00 & -0.21 & 0.20 \\
\hline Education (1=high) & $-0.43^{*}$ & -0.79 & -0.07 & -0.09 & -0.32 & 0.13 & -0.09 & -0.32 & 0.13 \\
\hline Employment (1=part-time) & -0.03 & -0.35 & 0.28 & -0.14 & -0.35 & 0.05 & -0.15 & -0.35 & 0.05 \\
\hline Previous assignment ( $1=$ yes) & 0.26 & -0.03 & 0.55 & $0.35^{* * *}$ & 0.17 & 0.53 & $0.35^{* * *}$ & 0.17 & 0.54 \\
\hline Fulfilment PC agency & & & & $0.79^{* * *}$ & 0.68 & 0.89 & $0.79^{* * *}$ & 0.68 & 0.89 \\
\hline Fulfilment PC host & & & & 0.07 & -0.04 & 0.18 & 0.07 & -0.04 & 0.18 \\
\hline \multicolumn{10}{|l|}{ Fulfilment PC agency X } \\
\hline Fulfilment PC host & & & & & & & -0.01 & -0.08 & 0.06 \\
\hline Adjusted R2 & .02 & & & .59 & & & .59 & & \\
\hline$\Delta \mathrm{R} 2$ Change & $.04^{*}$ & & & $.56^{* * *}$ & & & .00 & & \\
\hline F-statistic & 2.43 & & & 70.64 & & & 61.64 & & \\
\hline$\Delta$ F-statistic & 2.43 & & & 232.70 & & & 0.05 & & \\
\hline
\end{tabular}

Note: $\mathrm{N}=337$. Unstandardised regression coefficients are shown. Significance levels: $* \mathrm{p}<.05 ; * * \mathrm{p}<.01 ; * * * \mathrm{p}<.001$. PC $=$ psychological contract. 
FIGURE 1

The double psychological contracts of temporary agency workers

Figure 1: Hypothesised relationships between fulfilment of the psychological contract by agency and host and temps'job attitudes
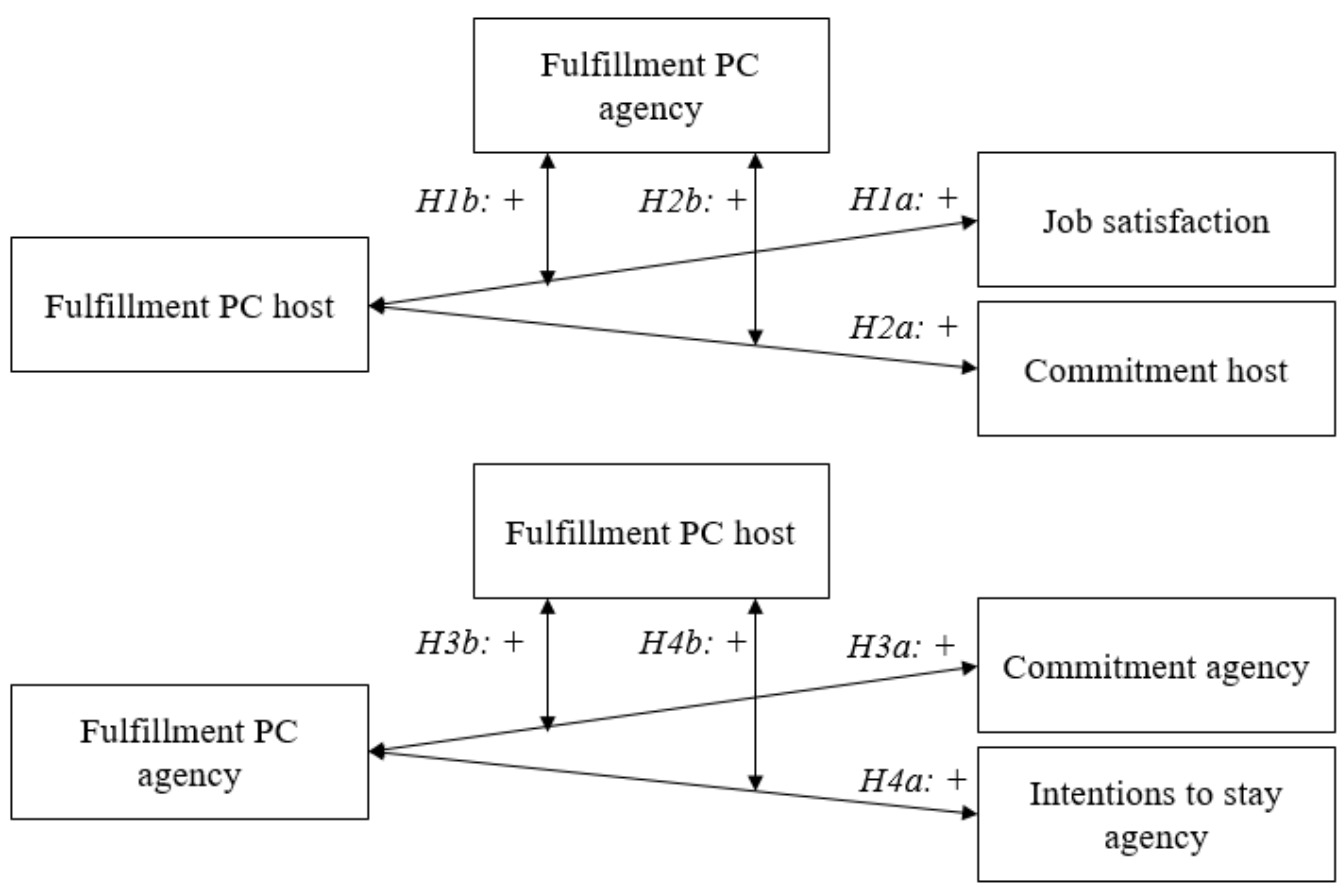

Note: $\mathrm{PC}=$ psychological contract. 
Figure 2 and Figure 3

The double psychological contracts of temporary agency workers

Figure 2: Interaction between fulfilment of the psychological contract by the agency and by the host predicting job satisfaction

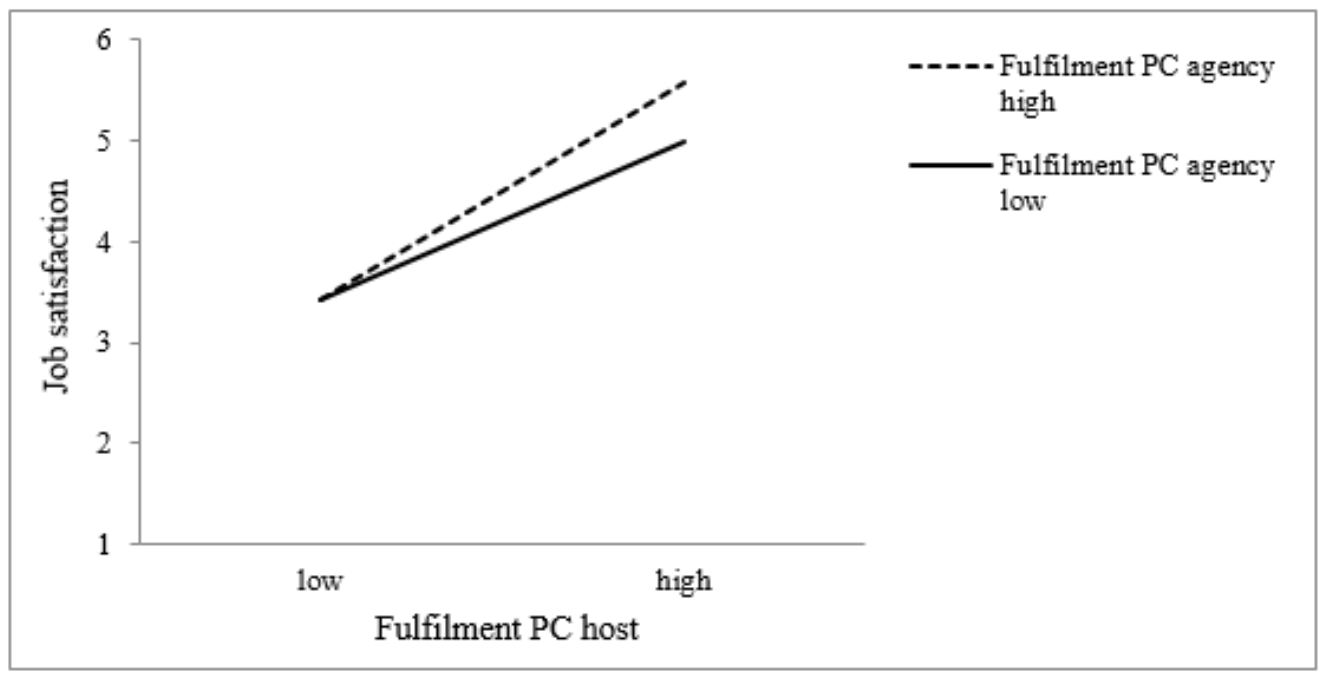

Note: Graph calculated for a 33.14 year old female temp employed full time, low educated, and with at least one previous assigment at the agency. Low fulfilment $=$ one standard deviation below mean; high fulfilment $=$ one standard deviation above mean $. \mathrm{PC}=$ psychological contract.

Figure 3: Interaction between fulfilment of the psychological contract by the agency and by the host predicting commitment towards the agency

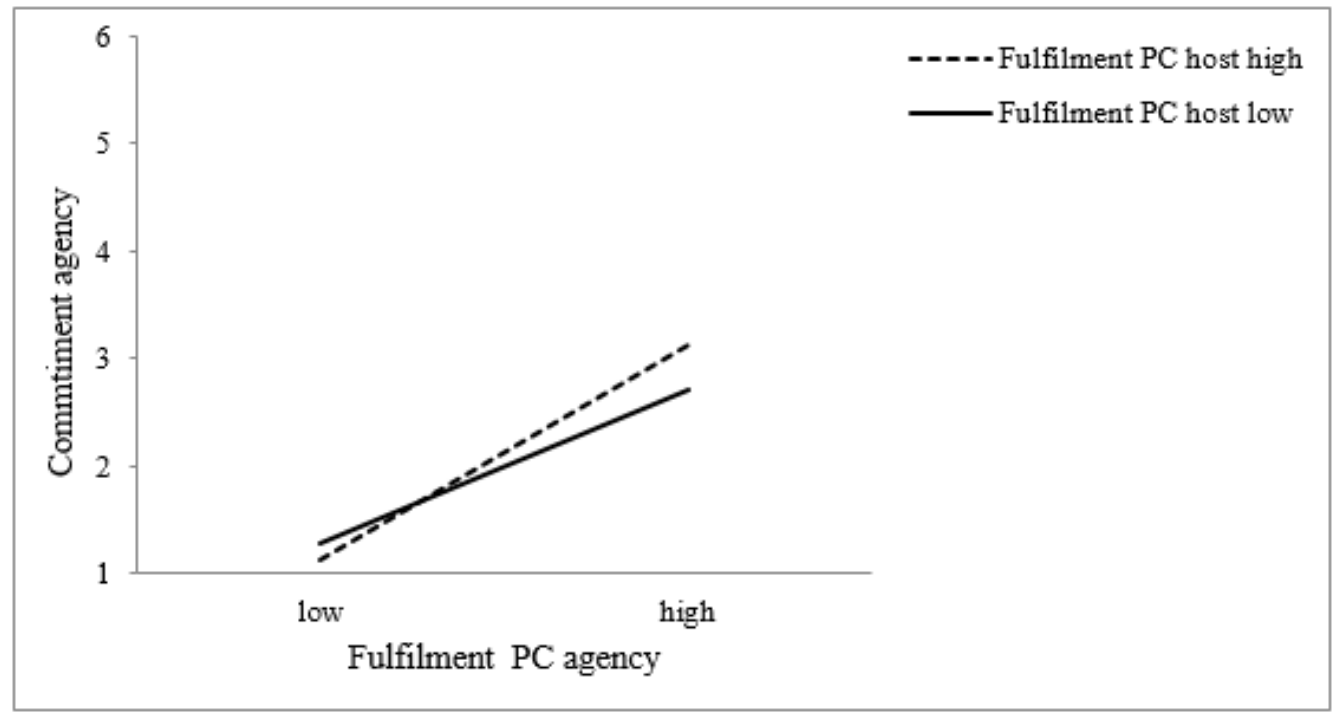

Note: Graph calculated for a 33.14 year old female temp employed full time, low educated, and with at least one previous assigment at the agency. Low fulfilment = one standard deviation below mean; high fulfilment $=$ one standard deviation above mean $. \mathrm{PC}=$ psychological contract. 